\title{
Modulation of IL-12 and IFN- $\gamma$ Secretions by Eleutheroside E, Tortoside A, and Syringaresinol from Acanthopanax koreanum Nakai
}

\author{
Su-Yun LYu', and Won-Bong PARK ${ }^{2, *}$ \\ ${ }^{1}$ Department of Herbal Medicinal Pharmacology, Daegu Haany University, Gyeongsan 712-715, \\ ${ }^{2}$ Department of Chemistry, College of Natural Sciences, Seoul Women's University, Seoul 139-774, Republic of Korea
}

(Received April 6, 2010; Revised April 17, 2010; Accepted April 19, 2010)

\begin{abstract}
Acanthopanax koreanum Nakai (Araliaceae) is a medicinal plant indigenous to Korea. The root and stem barks of Acanthopanax species have been used as a tonic and sedative as well as in the treatment of rheumatism and diabetes. In our study, three lignans, eleutheroside $E(E E)$, tortoside $A(T A)$, and syringaresinol (SY), were isolated from the stem and root of $A$. koreanum in an effort to study the immunomodulating effect. We treated natural killer cells and dendritic cells with lignans (EE, TA, or SY), and analyzed their cytokine (IL-12 and IFN- $\gamma$ ) secretion. EE, TA, or SY markedly enhanced IL-12 secretion in mouse lymphoid (DC1) and myeloid type (DC2.4) dendritic cells after $48 \mathrm{hr}$ of treatment. There were no significant differences in the cytokine stimulatory effects between EE, TA, or SY. Moreover, treatment of EE, TA, or SY significantly induced IFN- $\gamma$ secretion by human NK cells (NK92MI) confirmed by ELISA assay. This study suggests that lignans from $A$. koreanum modulate cytokines, and that such modulation may provide the mechanism of action for many of their therapeutic effects.
\end{abstract}

Keywords: Acanthopanax koreanum, IL-12, IFN- $\gamma$, Dendritic cells, NK cells

\section{INTRODUCTION}

Acanthopanax koreanum Nakai (Araliaceae) is a medicinal plant indigenous to Korea (Kim and Chung, 1988). The root and stem barks of Acanthopanax species have been used as a tonic and sedative as well as in the treatment of rheumatism and diabetes (Perry and Metzger, 1980). However, little is known about its effects in the immune system and its mechanisms of action. Lignans and neolignans, found in a wide range of plants, display numerous pharmacological activities (Pool-Zobel et al., 2000; Arroo et al., 2002). In view of the important pharmacological properties, numerous studies have been carried out in an attempt to get a better knowledge of the biological events linked to lignans isolated from Acanthopanax species (Kim et al., 1995; Yook et al., 1998; Ban et al., 2002; Lee et al., 2004; Lin et al., 2008; Nhiem et al., 2009). It was reported that lupane triterpene glycosides from leaves of $A$. koreanum showed cytotoxic activities against leukemia, lung and breast cancer cell lines (Nhiem et al., 2009). More-

${ }^{*}$ Corresponding author

Tel: +82-2-970-5655 Fax: +82-2-975-3159

E-mail: wbpark@swu.ac.kr over, $A$. senticosus stems and their lignan components possessed antioxidant and hepatoprotective activities (Lee et al., 2004).

Modulation of cytokine secretion may offer novel approaches in the treatment of a variety of diseases (Spelman et al., 2006). For example, in the field of oncology, progress has been made in the therapeutic use of several interleukins, including interleukin (IL)-4, -6, -11 and -12. One strategy in the modulation of cytokine expression may be through the use of herbal medicines (Oleksowicz and Dutcher, 1994). In light of the adverse events experienced with cytokine-targeted therapy, it could prove useful to consider the use of phytotherapy in the modulation of cytokine expression (Spelman et al., 2006).

Dendritic cells (DCs) and cytotoxic T lymphocytes (CTLs) are the first-line protecting barrier against different pathogens (viruses, bacteria and neoplasms cells) (Krawczyk et al., 2006). Several different DC populations have been identified, each of which is differentiated via a unique pathway. Two DC subsets of myeloid origin have been described: Langerhans cells (LCs), present in the epidermis, which take up antigen and subsequently migrate to local lymph nodes to differentiate into DCs; and myeloid-line- 
age-derived DCs, located in the dermis, blood, and B-cell follicles, which lack LC markers. There is also evidence for the existence of a distinct lymphoid DC subset, which is represented by the CD11c ${ }^{-}$plasmacytoid DC (Banchereau and Steinman, 1998). Following antigen uptake in the periphery, immature DCs change and migrate into secondary lymphoid organs, where they mature and must interact in an antigen-specific manner with $B$ cells and $T$ cells to initiate an immune response (Banchereau and Steinman, 1998; Vissers et al., 2001). Immature myeloid- and lymphoid dendritic cells possess ability to phagocytose and present antigens to lymphocytes. They have also ability to produce IL-12, which is also known as natural killer cell stimulatory factor or cytotoxic lymphocyte maturation factor (Krawczyk et al., 2006).

The notion currently prevailing is that natural killer (NK) cells can be rapidly activated in the periphery by chemokines and/or inflammatory cytokines in conjunction with NK cell stimulatory factors such as IL-12, interferon (IFN) type 1, or IL-2 (Zitvogel, 2002). In particular, IFN-gamma $(\gamma)$ is considered the prototypic NK cell cytokine, and its production by NK cells is known to shape the Th1 immune response (Mocikat et al., 2003), activate antigen presenting cells (APC) to further up-regulate MHC class I expression (Wallach et al., 1982), activate macrophage killing of obligate intracellular pathogens (Filipe-Santos et al., 2006), and have anti-proliferative effects on viral- and malignant-transformed cells (Maher et al., 2007).

In our study, three lignans, eleutheroside $E(E E)$, tortoside $A(T A)$, and syringaresinol (SY), were isolated from the stem and root of $A$. koreanum in an effort to study the immunomodulating effect. We treated natural killer cells (NK92MI) and dendritic cells (DC1 and DC2.4) with lignans, and analyzed their cytokine (IL-12 and IFN- $\gamma$ ) secretions.

\section{MATERIALS AND METHODS}

\section{Preparation of eleutheroside E, tortoside $A$, and syringa- resinol (EE, TA, or SY, respectively)}

Dried branches and roots of $A$. koreanum were purchased from Susin Ogapy Co. (Chunahn, Chungnam, Korea). Three lignans, eleutheroside $E(F i g .1 A)$, tortoside A (Fig. 1B), and syringaresinol (Fig. 1C), were isolated from the branch and root of $A$. koreanum and identified as reported previously (Kang et al., 2001; Cai et al., 2004) and provided by Dr. Jung-Jun Lee at Korea Research Institute of Bioscience \& Biotechnology (KRIBB), Daejun, Korea. The resulting solutions were filtered step by step through various membrane filter sizes $(0.8,0.45$, and $0.2 \mu \mathrm{m}$;
Nippon Milipore Ltd., Tokyo, Japan). The samples were stored in $-80^{\circ} \mathrm{C}$ until used.

\section{Cell culture}

Mouse lymphoid type dendritic cell (DC1) and myeloid type dendritic cell (DC2.4) lines were kindly provided by Professor J. S. Kang (College of Medicine, Seoul National University, Seoul, Korea). DC1 and DC2.4 cells were resuspended in complete tissue culture medium (CTCM) consisting of RPMI-1640 medium (Sigma, Poole, UK) supplemented with $5 \%$ fetal calf serum (FCS; Sigma, Poole, UK), $100 \mathrm{u} / \mathrm{ml}$ penicillin $/ 100 \mu \mathrm{g} / \mathrm{ml}$ streptomycin (Sigma, Poole, UK), $2 \mathrm{mM}$ L-glutamine (Sigma, Poole, UK), and $5 \times 10^{-5} \mathrm{M}(2-\mathrm{ME}$, Sigma, Poole, UK). Cell cultures were placed in $25-\mathrm{cm}^{2}$ flasks (Corning, NY, USA) and incubated at $37^{\circ} \mathrm{C}$ in a humidified, $5 \% \mathrm{CO}_{2}$ atmosphere. NK92MI cells, a human NK cell line transfected with human IL-2, were purchased from ATCC. Cells were maintained in alpha modification of minimum essential medium Eagle (alpha MEM; Gibco, NY, USA) supplemented with 12.5\% fetal bovine serum (FBS; Sigma, Poole, UK), $100 \mathrm{u} / \mathrm{ml}$

(A)<smiles>COc1cc(C2OC[C@H]3C(c4cc(OC)c(O[C@@H]5O[C@H](CO)[C@@H](O)[C@H](O)[C@H]5O)c(OC)c4)OCC23)cc(OC)c1O[C@@H]1O[C@H](CO)[C@@H](O)[C@H](O)[C@H]1O</smiles>

(B)<smiles>COc1cc(C2OC[C@H]3[C@H](c4cc(OC)c(O[C@@H]5O[C@H](CO)[C@@H](O)[C@H](O)[C@H]5O)c(OC)c4)OC[C@H]23)cc(OC)c1O</smiles>

(C)

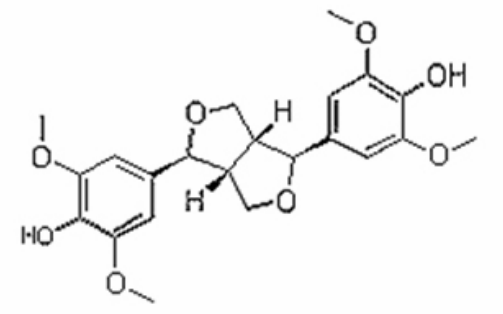

Fig. 1. Chemical structures of $(A)$ elutheroside $E,(B)$ tortoside $A$, and $(C)$ syringaresinol. 
penicillin $/ 100 \mu \mathrm{g} / \mathrm{ml}$ streptomycin (Sigma, Poole, UK), 2 $\mathrm{mM}$ L-glutamine (Sigma, Poole, UK), $0.2 \mathrm{mM}$ inositol (Sigma, Poole, UK), $20 \mathrm{mM}$ folic acid (Sigma, Poole, UK), $12.5 \%$ horse serum (Sigma, Poole, UK), and $5 \times 10^{-5} \mathrm{M}$ 2-mercaptoethanol (2-ME, Sigma, Poole, UK).

\section{Cell viability}

In vitro cell viability was measured using MTS (Promega, Southampton, UK) assay as previously described (Lyu and Park, 2008). Briefly, cells $\left(5 \times 10^{-5}\right.$ cells $/ \mathrm{ml}$ ) were added in 96-well flat bottomed tissue culture plates (NUNC, Life Technologies, Paisley, UK) in the absence or presence of EE, TA, or SY at various concentrations for $48 \mathrm{hr}$ at $37^{\circ} \mathrm{C}$ in a humidified $5 \% \mathrm{CO}_{2}$ atmosphere. At the end of the incubation, $40 \mu \mathrm{l}$ of combined MTS/phenazine methosulphate (PMS) solution was added into each well and further incubated for $4 \mathrm{hr}$ at $37^{\circ} \mathrm{C}$ in a humidified, $5 \% \mathrm{CO}_{2}$ atmosphere. Formazan produced was determined by measuring the absorbance at $450 \mathrm{~nm}$ with an ELISA reader (Dynex Technologies, Chantiliy, VA, USA). The optical density of formazan formed in untreated control cells was taken as $100 \%$ of viability.

\section{Enzyme-linked immunosorbent assay (ELISA) for cyto- kine secretions}

Lignans were diluted with cell culture medium and tested in triplicate wells. Lignans were added to cells stimulated with $100 \mathrm{ng} / \mathrm{ml}$ of LPS and incubated at $37^{\circ} \mathrm{C}$ in $5 \%$ $\mathrm{CO}_{2}$ atmosphere for $48 \mathrm{hr}$ and $100 \mu \mathrm{l}$ of culture supernantant was removed for the measurement of IL-12 and IFN- $\gamma$ productions. For determination of cytokine secretions, 96-well MaxiSorp (NUNC, Life Technologies, Paisley, UK) plates were coated with purified anti-mouse IL-12 monoclonal antibody (BD Pharmingen, UK) or purified anti-human IFN- $\gamma$ monoclonal antibody in binding buffer $(0.1$ $\mathrm{M} \mathrm{Na}_{2} \mathrm{HPO}_{4}$, adjusted to $\mathrm{pH} 9.0$ with $0.1 \mathrm{M} \mathrm{NaH}_{2} \mathrm{PO}_{4}$ ) overnight at $4^{\circ} \mathrm{C}$. After washing the plates three times, which contained phosphate buffered saline (PBS) with $0.5 \%(\mathrm{~V} / \mathrm{v})$ Tween 20 (Sigma), the plates were blocked with $1 \%(w / V)$ bovine serum albumin (BSA; Sigma) at room temperature for $2 \mathrm{hr}$. Following three washes, $50 \mu \mathrm{l}$ of cell culture supernatants were added and incubated overnight at $4^{\circ} \mathrm{C}$; for standards, recombinant IL-12 and IFN- $\gamma$ were included for each plate. After four washes, $100 \mu \mathrm{l}$ of biotinylated anti-IFN- $\gamma$ and IL-12 detection antibody which was diluted in $1 \%$ BSA in PBS- Tween were added and incublated at room temperature for $1 \mathrm{hr}$. Following four washes, the presence of biotinylated antibodies was detected with 1:1,000 dilution of streptavidin-peroxidase (BD Pharmingen). At the end of an hour incubation at room temperature, the plate were washed and developed using $0.1 \mathrm{mg} / \mathrm{ml}$ of 3,3, 5,5 'tetramethylbenzidine substrate (TMB; Sigma) solution. The enzyme reaction was stopped with $1 \mathrm{M} \mathrm{HCl}$ and the colorimetric development was read at $450 \mathrm{~nm}$ with an ELISA reader (Dynex Technologies).

\section{Statistical analysis}

Student $t$-test was used for comparisons (MINITAB ${ }^{\circledR}$, release 14.1, Minitab Inc., USA). Probability values ( $p$-value) of $<0.001,<0.01$, or $<0.05$ were considered significant with $99.9,99$, or $95 \%$ of confidence, respectively.

\section{RESULTS}

\section{Cytotoxic effects on DC1, DC2.4, and NK92MI cells}

Mouse dendritic cells (DC1 and DC2.4) and human NK cells (NK92MI) were treated for 48 hours with $A$. koreanum lignans at the indicated dose and the viability was measured using the MTS assay. More than $95 \%$ of the cells survived at concentrations lower than $10^{-4} \mathrm{~g} / \mathrm{ml}$ (Table I-III). The result obtained showed that the selected concentration (lower than $1 \mu \mathrm{g} / \mathrm{ml}$ ) of $A$. koreanum that was used for cytokine secretion assay had no major effect on the cells when compared to the controls.

\section{Effect of EE, TA, or SY on IL-12 secretion in DC1 cells}

Mouse lymphoid type DC1 cells were treated with EE, $\mathrm{TA}$, or SY to investigate whether $A$. koreanum lignans can change IL-12 secretion, which is related to anti-cancer activities. When lipopolysaccharide (LPS)-stimulated DC1 cells were treated with $10^{-8}-10^{-11} \mathrm{~g} / \mathrm{ml}$, EE shifted the LPS-induced IL-12 secretion toward a more immunostimulative response. However, in the concentration range of $10^{-12}-10^{-17} \mathrm{~g} / \mathrm{ml}$ of $\mathrm{EE}$, there was no significant change compared with LPS control, with the exception of $10^{-13}$ $\mathrm{g} / \mathrm{ml}$ which showed a significant increase of IL-12 (Fig. 2A). In the case of TA, a $30 \%$ increase of IL-12 secretion was observed at $5 \times 10^{-10} \mathrm{~g} / \mathrm{ml}$ and the most significant increase was observed at $10^{-8} \mathrm{mg} / \mathrm{ml}$. In the concentration range of $10^{-10}-10^{-12} \mathrm{~g} / \mathrm{ml}$, there was no significant change (Fig. 2B). When cells were treated with SY, there was a $40 \%$ increase in IL-12 secretion at $10^{-15} \mathrm{~g} / \mathrm{ml}$ and a $90 \%$ increase at $10^{-11} \mathrm{~g} / \mathrm{ml}$ (Fig. 2C).

\section{Effect of EE, TA, or SY on IL-12 secretion in DC2.4 cells}

Mouse myeloid type DC2.4 cells were treated with EE, TA, or SY and their effects on IL-12 secretion were observed. When LPS-stimulated DC2.4 cells were treated with $10^{-9}-10^{-10} \mathrm{~g} / \mathrm{ml}$ of $E E$, there was a $20-30 \%$ increase in IL-12 secretion but in the concentration range of $10^{-11}$. 
Table I. Cell viability (\%) of DC1 when treated with A. koreanum lignans (EE, TA, or SY). DC1 was cultured in absence or presence of different concentrations of EE, TA, or SY and the viability was measured by MTS assay. Experiments were performed at least three times and each point represents the mean of triplicate \pm SE

\begin{tabular}{ccccccc}
\hline \multirow{2}{*}{ A. koreanum } & \multicolumn{5}{c}{ Conc. $(\mathrm{g} / \mathrm{ml})$} \\
\cline { 2 - 6 } & Untreated & $10^{-8}$ & $10^{-7}$ & $10^{-6}$ & $10^{-5}$ & $10^{-4}$ \\
\hline EE & $100 \pm 0$ & $102 \pm 1$ & $100 \pm 2$ & $99 \pm 3$ & $98 \pm 2$ & $97 \pm 1$ \\
TA & $100 \pm 0$ & $101 \pm 2$ & $100 \pm 3$ & $99 \pm 1$ & $98 \pm 1$ & $97 \pm 1$ \\
SY & $100 \pm 0$ & $101 \pm 3$ & $100 \pm 2$ & $99 \pm 2$ & $98 \pm 3$ & $98 \pm 2$ \\
\hline
\end{tabular}

Table II. Cell viability (\%) of DC2.4 when treated with A. koreanum lignans (EE, TA, or SY). DC2.4 was cultured in absence or presence of different concentrations of EE, TA, or SY and the viability was measured by MTS assay. Experiments were performed at least three times and each point represents the mean of triplicate \pm SE

\begin{tabular}{cccrccc}
\hline \multirow{2}{*}{ A. koreanum } & \multicolumn{5}{c}{ Conc. $(\mathrm{g} / \mathrm{ml})$} \\
\cline { 2 - 6 } & Untreated & $10^{-8}$ & $10^{-7}$ & $10^{-6}$ & $10^{-5}$ & $10^{-4}$ \\
\hline EE & $100 \pm 0$ & $100 \pm 2$ & $100 \pm 4$ & $99 \pm 1$ & $99 \pm 2$ & $99 \pm 1$ \\
TA & $100 \pm 0$ & $102 \pm 2$ & $99 \pm 1$ & $98 \pm 2$ & $97 \pm 2$ & $96 \pm 3$ \\
SY & $100 \pm 0$ & $101 \pm 2$ & $102 \pm 1$ & $99 \pm 2$ & $97 \pm 1$ & $95 \pm 1$ \\
\hline
\end{tabular}

Table III. Cell viability (\%) of NK92MI when treated with A. koreanum lignans (EE, TA, or SY). NK92MI was cultured in absence or presence of different concentrations of EE, TA, or SY and the viability was measured by MTS assay. Experiments were performed at least three times and each point represents the mean of triplicate \pm SE

\begin{tabular}{ccccccc}
\hline \multirow{2}{*}{ A. koreanum } & \multicolumn{5}{c}{ Conc. $(\mathrm{g} / \mathrm{ml})$} \\
\cline { 2 - 7 } & untreated & $10^{-8}$ & $10^{-7}$ & $10^{-6}$ & $10^{-5}$ & $10^{-4}$ \\
\hline EE & $100 \pm 0$ & $102 \pm 1$ & $100 \pm 3$ & $98 \pm 1$ & $97 \pm 2$ & $96 \pm 1$ \\
TA & $100 \pm 0$ & $100 \pm 1$ & $100 \pm 2$ & $99 \pm 2$ & $98 \pm 3$ & $97 \pm 1$ \\
SY & $100 \pm 0$ & $102 \pm 2$ & $102 \pm 1$ & $100 \pm 2$ & $99 \pm 1$ & $98 \pm 2$ \\
\hline
\end{tabular}

$10^{-17} \mathrm{~g} / \mathrm{ml}$, there was no significant change (Fig. 3A). When the cells were treated with SY, there was an increase at $10^{-11}-10^{-14} \mathrm{~g} / \mathrm{ml}$ and the most significant IL-12 secretion was shown when treated with $10^{-13} \mathrm{~g} / \mathrm{ml}$ (Fig. $3 B$ ). There was a less significant increase of IL-12 when DC2.4 cells were treated with SY. We could see an IL-12 secretion at $10^{-12}-10^{-13} \mathrm{~g} / \mathrm{ml}$, but there was no change at $10^{-14}-10^{-17} \mathrm{~g} / \mathrm{ml}$ and concentrations above $10^{-11} \mathrm{~g} / \mathrm{ml}$ (Fig. 3C).

\section{Effect of EE, TA, or SY on IFN- $\gamma$ secretion in NK92MI cells}

Further studies were carried out to determine if $A$. koreanum lignans are able to effect the secretion of IFN- $\gamma$ in human NK cells. IN LPS-stimulated NK-cells, EE significantly shifted the IFN- $\gamma$ secretion toward a more immunostimulatory response. Particularly, an increase of IFN- $\gamma$ was observed in the presence of EE $\left(10^{-13}-10^{-19} \mathrm{~g} / \mathrm{ml}\right)$ compared with LPS controls (Fig. 4A). When the cells were treated with TA, we could see a similar secretion pattern to EE. There was a $30 \%$ increase in IFN- $\gamma$ secretion at $10^{-13} \mathrm{~g} / \mathrm{ml}$, and the most significant increase was observed at $10^{-7}$ $\mathrm{mg} / \mathrm{ml}$. However, IFN- $\gamma$ secretion started to decrease when the cells were treated with the concentration higher than $10^{-6} \mathrm{~g} / \mathrm{ml}$ (Fig. 4B). In the case of SY, we could see a gradual increase in IFN- $\gamma$ secretion in a dose-dependant manner. There was a $40 \%$ increase of IFN- $\gamma$ at $10^{-9} \mathrm{~g} / \mathrm{ml}$ of SY. On the other hand, in the concentration range of $10^{-15}$ $10^{-17} \mathrm{~g} / \mathrm{ml}$, there was no significant change compared to the controls (Fig. 4C).

\section{DISCUSSION}

Immune-related illnesses have long been treated with herbal medicines. In regard to phytotherapy, immunomodulators may be defined as botanical medicines that alter the activities of the immune system via the dynamic regulation of informational molecules - cytokines, chemokines, and other peptides (Spelman et al., 2006). Acanthopanax koreanum Nakai is a native plant that grows on Jeju Island, located in the south of Korea (Nan et al., 2004). Previously, it was reported that acanthoic acid, a diterpene isolated from the root bark of Acanthopanax koreanum, inhibited IL-1 and TNF- $\alpha$ production by human monocyte/macrophages (Kang et al., 1996) and showed potent inhibitory 

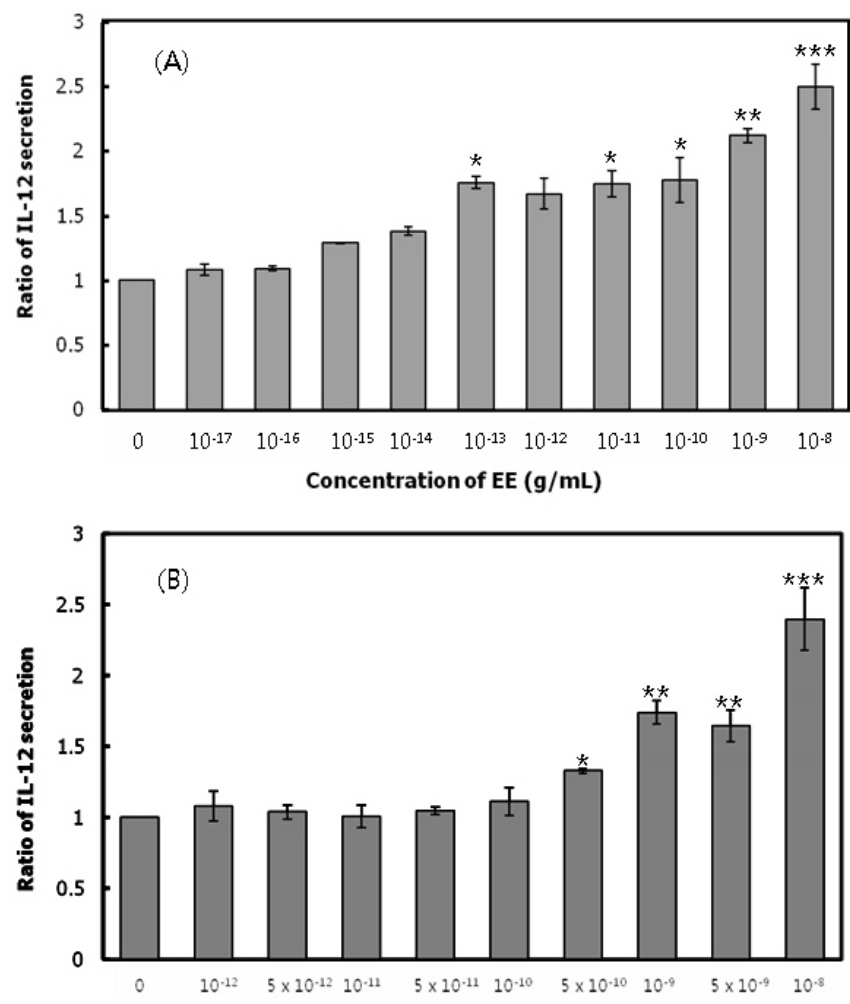

Concentration of TA $(\mathrm{g} / \mathrm{mL})$

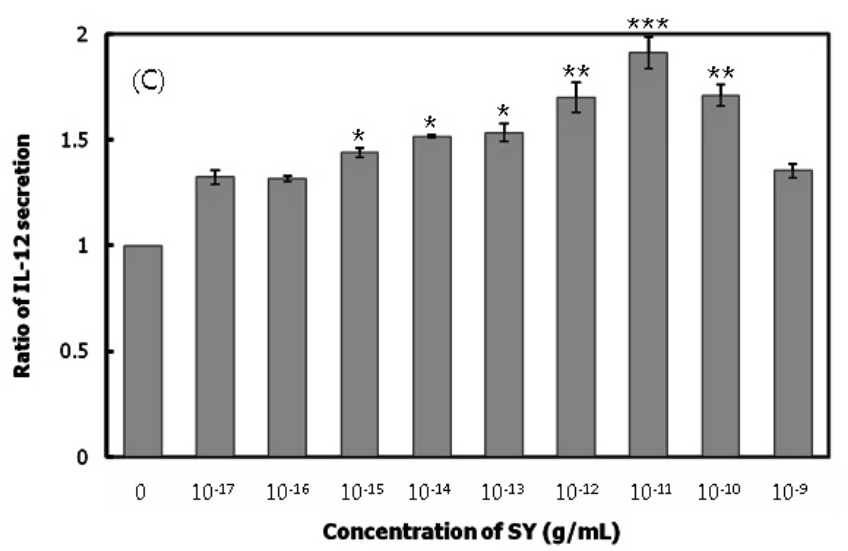

Fig. 2. Effect of lignans (A) EE, (B) TA, and (C) SY on the secretion of IL-12 in LPS (100 ng/ml)-stimulated DC1 cells. Values represent the mean \pm standard deviation from at least three independent experiments with whole cells. Student's $t$-test was used to compare each of the treatment group with the control group, and the significance was determined. ${ }^{*} p<0.05$, ${ }^{* *} p<0.01,{ }^{* * *} p<0.001$.

activity on IL-8 secretion by human colon adenocarcinoma cell line (Cai et al., 2003). Moreover, acanthoic acid inhibited TNF- $\alpha$-medicated IL- 8 production by blocking in both the MAPKs and NF- $\kappa B$ pathways in human colon epithelial cells (Kim et al., 2004).

The lignans are a group of chemical compounds found
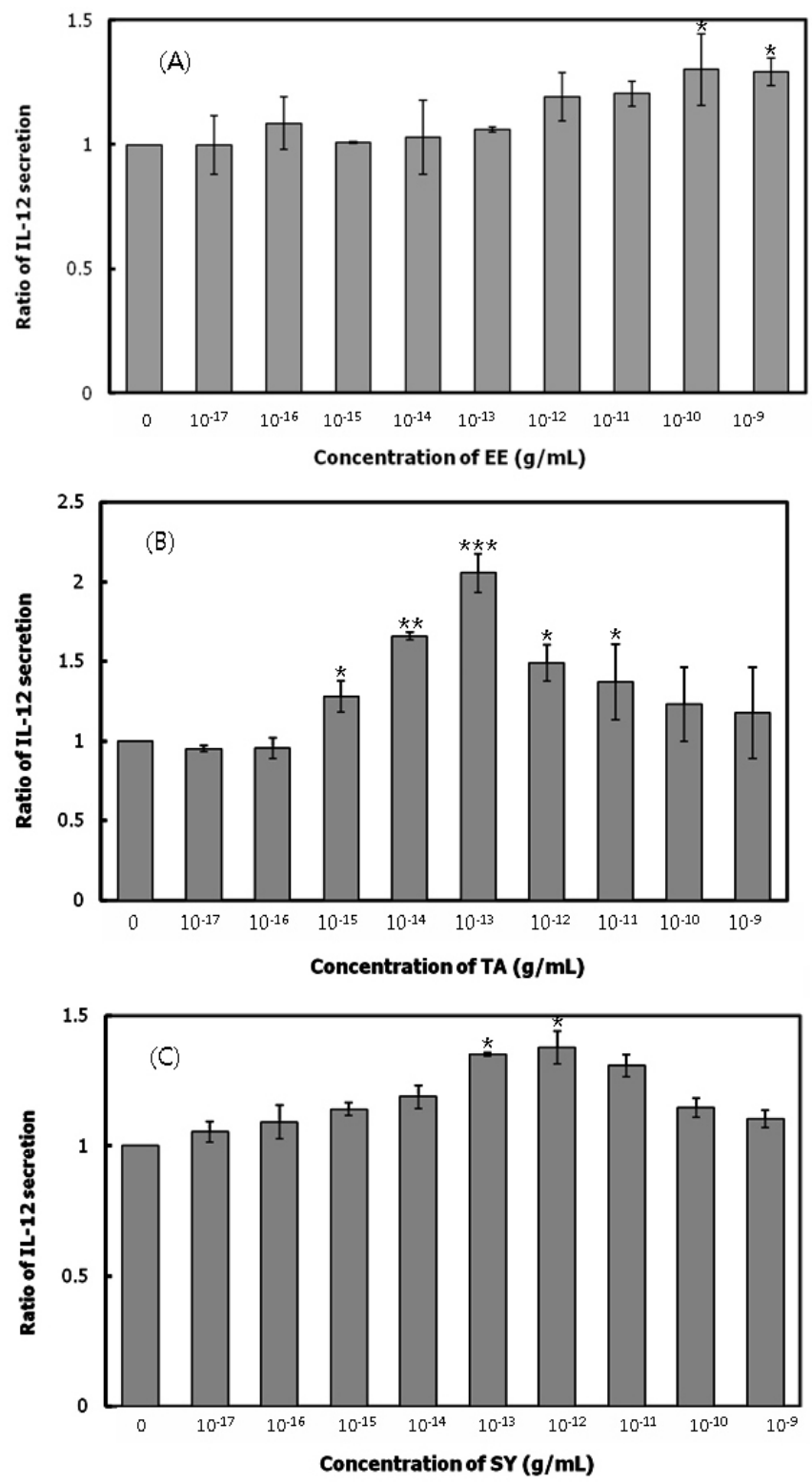

Fig. 3. Effect of lignans (A) EE, (B) TA, and (C) SY on the secretion of IL-12 in LPS (100 ng/ml)-stimulated DC2.4 cells. Values represent the mean \pm standard deviation from at least three independent experiments with whole cells. Student's $t$-test was used to compare each of the treatment group with the control group, and the significance was determined. ${ }^{*} p<0.05$, ${ }^{* *} p<0.01,{ }^{* * *} p<0.001$.

in plants. Lignans are one of the major classes of phytoestrogens, which are estrogen-like chemicals and also act as antioxidants (Messina and Barnes, 1991; Murkies et al., 1998). Plant lignans are polyphenolic substances derived from phenylalanine. Lignan-containing food include legumes, seeds, cereals/grain, berries, dried fruit, and vegetables (Thompson et al., 2006). Lignans are being studied 

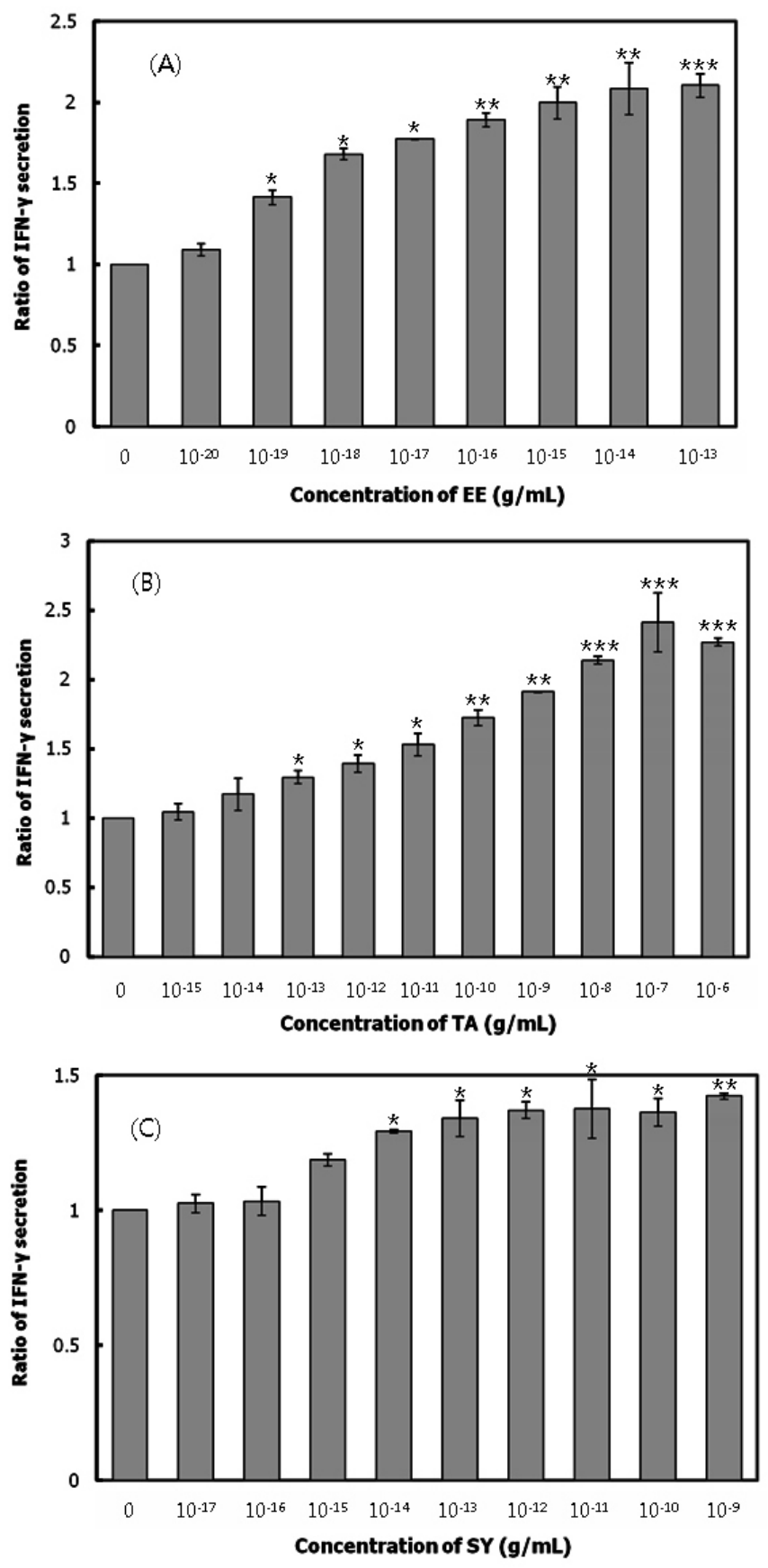

Fig. 4. Effect of lignans (A) EE, (B) TA, and (C) SY on the secretion of IFN- $\gamma$ in LPS $(100 \mathrm{ng} / \mathrm{ml})$-stimulated NK92Ml cells. Values represent the mean \pm standard deviation from at least three independent experiments with whole cells. Student's $t$-test was used to compare each of the treatment group with the control group, and the significance was determined. ${ }^{*} p<0.05$, ${ }^{* *} p<0.01,{ }^{* * *} p<0.001$.

for possible use in cancer prevention. Lignans acts as anticancer compounds by blocking powerful growth factor re- ceptors like epidermal growth factor (EGF), Her2, insulin like growth factor-1, and vascular endothelial growth factor (VEGF), the hormone responsible for stimulating blood vessels into tumors (Thompson et al., 2005; Wang et al., 2005; Cotterchio et al., 2006). Several studies on lignans from $A$. koreanum have been reported. Lupane-triterpene glycoside, acankoreoside I, showed growth inhibitory effect in lung cancer, breast cancer, and leukemia cell lines (Nhiem et al., 2009). Also, three lignans isolated from the root, namely eleutheroside $E$, tortoside $A$, and hemiariensin, exhibited potent inhibitory activity against NFAT transcription factor (Cai et al., 2004). However, there were no studies which confirmed its pharmacological effects regarding cytokine secretion and its relevance to cancer.

Since $A$. koreanum have been traditionally used to treat immune-related illnesses (Nan et al., 2004), we studied the Th1 cytokine secretion effect of lignans (EE, TA, or SY) isolated from $A$. koreanum. Dendritic cells (DCs) produce IL-12, which plays a major role in resistance to tumors, bacterial, and viral infections (Trinchieri, 1998). Depending on the conditions, DCs can stimulate the outgrowth and activation of a variety of T cells, which affect the immune response differently. In the presence of mature DCs and of the IL-12 they produce (Cella et al., 1996; Koch et al., 1996; Reis e Sousa et al., 1997), these T cells turn into IFN- $\gamma$ producing Th1 cells. In the present study, we found that lignans from $A$. koreanum markedly enhanced IL-12 secretion in lymphoid and myeloid type dendritic cells after $48 \mathrm{hr}$ of treatment. Three lignans, EE, TA (one carbohydrate removed from EE), or SY (two carbohydrates removed from EE) were used to treat dendrtic cells. The reason for this is to determine whether the hydrophobic/hydrophilic characteristics have different effects on cytokine secretion in the cells. For example, carbohydrates are highly soluble in water so when it is removed from the lignan, the compound becomes more hydrophobic. Small hydrophobic molecules will pass the cell membrane easily, but larger, hydrophilic molecules will require a transport protein to allow permeability. Since lignans are small molecules that have a low molecular weight, becoming more hydrophobic may allow the compound to penetrate the cell membrane easier. Since SY is the most hydrophobic lignan, we assumed that SY would be more effective than EE or TA. However, there were no significant differences in the cytokine stimulatory effects between EE, TA, or SY. This is probably due, in part, to the fact that although TA and SY are more hydrophobic than EE, this characteristic doesn't lead to enhanced cytokine secretion.

Most likely, cells are seldom exposed to only a single cytokine. Rather, combinations of cytokines and other 
messenger molecules generate biologically relevant informational cues (Gabay and Kushner, 1999). Mature dendritic cells produce IL-12, essential not just for attraction of NK cells, cytolytic $T$ cells, and for shifting helper $T$ cell responses in a Th1 direction (Morse et al., 1998). Therefore, we used human NK cells to further evaluate the immunostimulating effects of $A$. koreanum lignans. After encounter with a pathogen or a danger, immature DCs mature and induce resting NK cell activation. NK cells are innate cytotoxic effectors but also regulatory cells releasing cytokines involved in innate resistance and adaptive immunity. In particular, IFN- $\gamma$ is considered the prototypic NK cell cytokine, and its production by NK cells is known to shape the Th1 immune response (Mocikat et al., 2003). They are required in resistance to tumors expressing ligands for activating receptors, and in the regulation of $B$ cell responses and autoimmunity (Shi et al., 2001; Zitvogel, 2002). As shown in the results above, treatment of lignans (EE, TA, or SY) of $A$. koreanum markedly induced IFN- $\gamma$ secretion confirmed by ELISA assay. Smiliar to the IL-12 secretion results by dendritic cells, there were no significant differences in the IFN- $\gamma$ stimulatory effects between EE, TA, or SY. IFN- $\gamma$ activates the antitumor activities of macrophages and, together with IL-12, it promotes the differentiation of T cells into killer cells. So the capacity of DCs to produce IL-12 and Th1 cells will lead to tumor, viral, and microbial resistance (Banchereau and Steinman, 1998). Further research may find that components of $A$. koreanum affecting multiple cytokines can each generate a unique signature of immune perturbation dependent on the concerted effect on arrays of cytokines.

The reported therapeutic success of $A$. koreanum by traditional cultures may be partially due to their effects on cytokines. This study suggests that lignans from $A$. koreanum modulate cytokines, and that such modulation may provide the mechanism of action for many of their therapeutic effects.

\section{ACKNOWLEDGMENTS}

This work was supported by a special research grant from Seoul Women's University in the program year of 2010.

\section{REFERENCES}

Arroo, R. R. J., Alfermann, A. W., Medarde, M., Petersen, M., Pras, N. and Woolley, J. G. (2002). Plant cell factories as a source for anti-cancer lignans. Phytochem. Rev. 1, 27-35.

Ban, H. S., Lee, S., Kim, Y. P., Yamaki, K., Shin, K. H. and Ohuchi, K. (2002). Inhibition of prostaglandin E2 production by taiwanin $\mathrm{C}$ isolated from the root of Acanthopanax chiisanensis and the mechianism of action. Biochem. Pharmcol. 64, 1345-1354.

Banchereau, J. and Steinman, R. M. (1998). Dendritic cells and the control of immunity. Nature 392, 245-252.

Cai, X. F., Lee, I. S., Dat, N. T., Shen, G., Kang, J. S., Kim, D. H. and Kim, Y. H. (2004). Inhibitory lignans against NFAT transcription factor from Acanthopanax koreanum. Arch. Pharm. Res. 27, 738-741.

Cai, X. F., Shen, G., Dat, N. T., Kang, O. H., Kim, J. A., Lee, Y. M., Lee, J. J. and Kim, Y. H. (2003). Inhibitory effect of TNF-alpha and IL-8 secretion by pimarane-type diterpenoids from Acanthopanax koreanum. Chem. Pharm. Bull. (Tokyo) 51, 605-607.

Cella, M., Scheidegger, D., Palmer-Lehmann, K., Lane, P., Lanzavecchia, A. and Alber, G. (1996). Ligation of CD40 on dendritic cells triggers production of high levels of interleukin-12 and enhances T cell stimulatory capacity: T-T help via APC activation. J. Exp. Med. 184, 747-752.

Cotterchio, M., Boucher, B. A., Manno, M., Gallinger, S., Okey, A. and Harper, P. (2006). Dietary phytoestrogen intake is associated with reduced colorectal cancer risk. J. Nutr. 136 3046-3053.

Filipe-Santos, O., Bustamante, J., Chapgier, A., Vogt, G., de Beaucoudrey, L., Feinberg, J., Jouanguy, E., BoissonDupuis, S., Fieschi, C., Picard, C. and Casanova, J. L. (2006). Inborn errors of IL-12/23- and IFN-gamma-mediated immunity: molecular, cellular, and clinical features. Semin. Immunol. 18, 347-361.

Gabay, C. and Kushner, I. (1999). Acute-phase proteins and other systemic responses to inflammation. N. Engl. J. Med. 340, 448-454.

Kang, H. S., Kim, Y. H., Lee, C. S., Lee, J. J., Choi, I. and Pyun, K. H. (1996). Suppression of interleukin-1 and tumor necrosis factor-alpha production by acanthoic acid, (-)pimara-9(11),15-dien-19-oic acid, and it antifibrotic effects in vivo. Cell Immun. 170, 212-221.

Kang, J. S., Linh, P. T., Cai, X. F., Kim, H. S., Lee, J. J. and Kim, Y. H. (2001). Quantitative determination of eleutheroside B and $E$ from Acanthopanax species by high performance liquid chromatography. Arch. Pharm. Res. 24, 407-411.

Kim, J. A., Kim, D. K., Jin, T., Kang, O. H., Choi, Y. A., Choi, S. C., Kim, T. H., Nah, Y. H., Choi, S. J., Kim, Y. H., Bae, K. H. and Lee, Y. M. (2004). Acanthoic acid inhibits IL-8 production via MAPKs and NF-kappaB in a TNF-alpha-stimulated human intestinal epithelial cell line. Clin. Chim. Acta. 342, 193-202.

Kim, Y. H. and Chung, B. S. (1988). Pimaradiene diterpenes from Acanthopanax koreanum. J. Nat. Prod. 51, 1080-1083.

Kim, Y. H., Kim, H. S., Lee, S. W., Uramoto, M. and Lee, J. J. (1995). Kaurane derivatives from Acanthopanax koreanum. Phytochemistry. 39, 449-451.

Koch, F., Stanzl, U., Jennewein, P., Janke, K., Heufler, C., Kampgen, E., Romani, N. and Schuler, G. (1996). High level IL-12 production by murine dendritic cells: upregulation via MHC class II and CD40 molecules and downregulation by IL-4 and IL-10. J. Exp. Med. 184, 741-746.

Krawczyk, P., Wojas, K., Milanowski, P. and Roliński, J. (2006). Myeloid and lymphoid dendritic cells and cytotoxic T lymphocytes in peripheral blood of non-small cell lung cancer patient--a pilot study. Adv. Med. Sci. 51, 160-163. 
Lee, S., Son, D., Ryu, J., Lee, Y. S., Jung, S. H., Kang, J., Lee, S. Y., Kim, H. S. and Kuk, H. S. (2004). Anti-Oxidant Activities of Acanthopanax senticosus Stems and their Lignan components. Arch. Pharm. Res. 27, 106-110.

Lin, Q. Y., Jin, L. J., Cao, Z. H. and Xu, Y. P. (2008). Nhibition of inducible nitric oxide synthase by Acanthopanax senticosus extract in RAW264.7 macrophages. J. Ethnopharmacol. 118, 231-236.

Lyu, S. Y. and Park, W. B. (2008). Th1/Th2 cytokine modulation in human PBMC by Acanthopanax divaricatus var. albeofructus. Food Sci. Biotechnol. 17, 631-636.

Maher, S. G., Romero-Weaver, A. L., Scarzello, A. J. and Gamero, A. M. (2007). Interferon: cellular executioner or white knight? Curr. Med. Chem. 14, 1279-1289.

Messina, M. and Barnes, S. (1991). The role of soy products in reducing risk of cancer. J. Natl. Cancer Inst. 83, 541-546.

Mocikat, R., Braumuller, H., Gumy, A., Egeter, O., Ziegler, H., Reusch, U., Bubeck, A., Louis, J., Mailhammer, R., Riethmuller, G., Koszinowski, U. and Rocken, M. (2003). Natural killer cells activated by MHC class I (low) targets prime dendritic cells to induce protective CD8 T cell responses. Immunity 19, 561-569.

Morse, M. A., Lyerly, H. K., Gilboa, E., Thomas, E. and Nair, S. K. (1998). Optimization of the sequence of antigen loading and CD40-ligand-induced maturation of dendritic cells. Cancer Res. 58, 2965-2968.

Murkies, A. L., Wilcox, G. and Davis, S. R. (1998). Clinical review 92: Phytoestrogens. J. Clin. Endocrinol. Metab. 83, 297-303.

Nan, J. X., Park, E. J., Nam, J. B., Zhao, Y. Z., Cai, X. F., Kim, Y. H., Sohn, D. H. and Lee, J. J. (2004). Effect of Acanthopanax koreanum nakai (Araliaceae) on D-galactosamine and lipopolysaccharide-induced fulminant hepatitis. J. Ethnopharmacol. 92, 71-77.

Nhiem, N. X., Tung, N. H., Kiem, P. V., Minh, C. V., Ding, Y., Hyun, J. H., Kang, H. K. and Kim, Y. H. (2009). Lupane triterpene glycosides from leave of Acanthopanax koreanum and their cytotoxic activity. Chem. Pharm. Bull. (Tokyo) 57, 986-989.

Oleksowicz, L. and Dutcher, J. P. (1994). A review of the new cytokines: IL-4, IL-6, IL-11, and IL-12. Am. J. Ther. 1, 107115.

Perry, L. M. and Metzger, J. (1980). Medicinal plants of East and Southeast Asia. MIT Press., Cambridge, MA, London.

Pool-Zobel, B. L., Aldercreutz, H., Glei, M., Liegibel, U. M., Sittlington, J., Rowland, I., Wahala, K. and Rechkemmer, G. (2000). Isoflavonoids and lignans have different potentials to modulate oxidative genetic damage in human colon cells. Carcinogenesis 21, 1247-1252.

Reis e Sousa, C., Hieny, S., Scharton-Kersten, T., Jankovic, D. Charest, H., Germain, R. N. and Sher, A. (1997). In vivo microbial stimulation induces rapid CD40 ligand-independent production of interleukin 12 by dendritic cells and their redistribution to T cell areas. J. Exp. Med. 186, 1819-1829.

Shi, F. D., Ljunggren, H. G. and Sarvetnick, N. (2001). Innate immunity and autoimmunity: from self-protection to selfdestruction. Trends Immunol. 22, 97-101.

Spelman, K., Burns, J., Nichols, D., Winters, N., Ottersberg, S. and Tenborg, M. (2006). Modulation of cytokine expression by traditional medicines: a review of herbal immunomodulators. Altern. Med. Rev. 11, 128-150.

Thompson, L. U., Boucher, B. A., Liu, Z., Cotterchio, M. and Kreiger, N. (2006). Phytoestrogen content of foods consumed in Canada, including isoflavones, lignans, and coumestan. Nutr. Cancer 54, 184-201.

Thompson, L. U., Chen, J. M., Li, T., Strasser-Weippl, K. and Goss, P. E. (2005). Dietary flaxseed alters tumor biological markers in postmenopausal breast cancer. Clin. Cancer Res. 11, 3828-3835.

Trinchieri, G. (1998). Interleukin-12: a cytokine at the interface of inflammation and immunity. Adv. Immunol. 70, 83-243.

Vissers, J. L. M., Hartgers, F. C., Lindhout, E., Teunissen, M. B. M., Figdor, C. G. and Adema, G. A. (2001). Quantitative analysis of chemokine expression by dendritic cell subsets in vitro and in vivo. J. Leukoc. Biol. 69, 785-793.

Wang, L., Chen, J. and Thompson, L. U. (2005). The inhibitory effect of flaxseed on the growth and metastasis of estrogen receptor negative human breast cancer xenograftsis Attributed to both its lignan and oil components. Int. J. Cancer 116, 793-798.

Yook, C. S., Kim, I. H., Hahn, D. R., Nohara, T. and Chang, S. Y. (1998). A lupane-triterpene glycoside from leaves of two Acanthopanax. Phytochemistry 49, 839-843.

Zitvogel, L. (2002). Dendritic and natural killer cells cooperate in the control/switch of innate immunity. J. Exp. Med. 195, F9F14. 